\title{
THE NEW OFFICIAL TOURISM WEBSITE OF THE CITY OF PORTO: PROMOTING TOURISM AND A WINE DESTINATION
}

\author{
João Pedro Capelo \\ Porto Digital Association (jpcapelo@portodigital.pt) \\ Susana Ribeiro, Maria José Ferreira, Ana Paula Marques \\ Dpt. Tourism Porto City Hall \\ Fernando Russel Pinto \\ ICT Dpt. Porto City Hall \\ Alexandre Valente Sousa \\ Porto Digital Association, Instituto Superior da Maia
}

\begin{abstract}
The new website of the city of Porto (www.visitporto.travel), that started development in early 2010 and was activated in May 2011, functions as a tourism marketplace combined with an integrated information system for tourism. This is achieved by combining a series of tools and technologies that provide information and advice and support the acquisition of goods and services. Starting from the early stage of trip planning and remote access (telephone, SMS, email and web), proceeding to the arrival into the city and face to face interactions in e.g. tourist shops, combined with other means of self-information and acquisition of goods and services (e.g. PortoCard), supporting the visit all the way up to eventually leaving the city to visit other destinations, such as the vineyards of the Douro Valley, and coming back to Porto for the return journey, and finishing with the process of feedback and follow-up. This paper describes the rationale behind the creation of this website that intends to be a tourism gateway to the Metropolitan Area of Porto and Northern Portugal with special emphasis on the Douro Valley, and the experience behind the process of designing, implementing and rolling out the new portal, and adapting it to user feedback. Although the website is still under active development some parts of it are already considered to be a success. The most important result seems to be that the website is working as a rally point for the tourism ecosystem, fostering the development of synergies between the different players.
\end{abstract}

Keyword: Wine; Tourism; destination; TIC and tourism

Resumo: O novo portal de Turismo da cidade do Porto: promoção de um destino Turismo e Vitivinícola. 
O novo portal de turismo da cidade do Porto (www.visitporto.travel), cujo desenvolvimento arrancou no início de 2010 sendo disponibilizado ao público em maio 2011, funciona como um mercado de turismo combinado com um sistema de informação integrado. Isto é conseguido através da combinação de uma série de ferramentas e tecnologias que fornecem informação e aconselhamento e apoiam a aquisição de bens e serviços turísticos.

O suporte vai desde a fase inicial de planeamento da viagem e acesso remoto (telefone, SMS, e-mail e web), prosseguindo com a chegada à cidade e interações face a face, por exemplo em lojas do turismo, combinado com outros meios de auto informação e aquisição de bens e serviços (por exemplo, PortoCard), apoiando a visita ao longo de todo o percurso até eventualmente deixar a cidade para visitar outros destinos, tal como as vinhas do Vale do Douro, voltando ao Porto para a viagem de regresso, e terminando com o processo de feedback e acompanhamento posterior.

Este artigo descreve a lógica da criação deste sítio web que pretende ser uma porta de entrada do turismo para a Área Metropolitana do Porto e Norte de Portugal, com especial destaque para o vinho e o Vale do Douro; e descreve a experiência por trás do processo de conceção, implementação e operacionalização deste novo portal, e adaptação do mesmo em função do feedback dos utilizadores.

Embora ainda esteja em ativo desenvolvimento, algumas componentes deste portal já são consideradas um sucesso. $O$ resultado mais importante parece ser estar funcionando como um ponto de encontro para o ecossistema do turismo, fomentando o desenvolvimento de sinergias entre os diferentes intervenientes.

Palavra-chave: Vinho; Turismo; destino; TIC e Turismo

Resumen: El nuevo sitio web de turismo de la ciudad de Oporto: la promoción del turismo y de un destino de vino

El nuevo sitio web de la ciudad de Oporto (www.visitporto.travel), que comenzó a desarrollarse a principios de 2010 y se activó en mayo de 2011, funciona como un mercado turístico combinado con un sistema de información integrado para el turismo. Esto se logra mediante la articulación de una serie de herramientas y tecnologías que proporcionan información, asesoramiento y apoyo en la adquisición de bienes y servicios. Así, desde la fase inicial de planificación del viaje y del acceso remoto a la información (teléfono, SMS, correo electrónico y web), la llegada a la ciudad ofrece una interacción cara a cara, por ejemplo, en tiendas para turistas, junto con otros medios de auto-información y compra de bienes y servicios (por ejemplo, PortoCard) que apoyan la visita y la programación de la salida de la ciudad para conocer otros destinos, como los viñedos del Valle del Duero, y de vuelta a Oporto para el viaje de regreso concluir así el proceso de retroalimentación y seguimiento. Este artículo describe la lógica inherente a la creación del sitio web referido que pretende ser una puerta de entrada para el turismo en el Área Metropolitana de Oporto y Norte de Portugal, con especial énfasis en el Valle del Duero, y la experiencia integral de la concepción, implementación e implantación del nuevo portal, para adaptarlo a la retroalimentación del usuario. Aunque el sitio está todavía en desarrollo, algunos de sus componentes ya se consideran un éxito. El resultado más importante parece radicar en el hecho de que el sitio web está funcionando como un punto de encuentro para el ecosistema del turismo, impulsando el desarrollo de sinergias entre los diferentes agentes.

Palabras clave: Vino, turismo, destino, TIC y turismo 


\section{INTRODUCTION}

Porto's new tourism portal appears in a context of trying to contribute to tourism growth in the region of Porto and Northern Portugal. The new portal was Porto's answer to the challenge of a qualitative and quantitative improvement of its information system for tourism, in order to better serve the needs of the municipality, region, tourists, visitors, investors, entrepreneurs, students and citizens and business in general. Porto is thus seen as the natural entry point for those interested in wine and the vineyards of the Douro Valley.

The market is increasingly demanding with regard to the use of digital channels, such as the Internet (Buhalis, 2008). For Porto this situation was aggravated by the fact that the installed system did not respond to the needs and expectations of end users for a simple, safe and convenient interface that managed multiple channels of interaction between the offer and the demand. On the other hand nowadays end users expect to be allowed a participatory role, and not being mere recipients / consumers of information or services (Page 2009).

The remaining of this paper is organized as follows. Section 2 characterizes the target destinations. Section 3 presents the tourism website as a marketplace. Section 4 presents the rationale behind the creation of the website.Section 5 presents the structure of the website and Section 6 its information architecture. Section 7 describes the development of the project and discusses the main issues, Section 8 presents related work, and Section 9 presents the conclusion.

\section{THE DESTINATION PORTO AND NORTHERN PORTUGAL}

Tourism has established itself as a sector bet in Northern Portugal since, in recent years, the region made a large effort on the cooperation of regional institutions with local tourism and business associations, aligning the corresponding policies and instruments to strengthen the national and regional branding of Porto and Northern Portugal.

All that means to strengthen, both domestically and internationally, the brand Porto and Northern Portugal is seen as a significant aid in economic development for much-needed increases in income and employment of the population in a deprived region, involving, among others, the possibility of job creation, recovery and revitalization of heritage (material and immaterial), the improvement of the urban and rural environment, the setting of skilled labour so that, together with other initiatives locally, regionally and nationally, Porto can contribute to "generate a level of production of tradable goods and services that will recover the path of convergence at the European level, ensuring a sustainable, additional income and employment of its population and promoting, in this way, the economic, social and territorial cohesion in Northern Portugal" (Comissão de Coordenação e Desenvolvimento Regional do Norte 2011). 
The destination Porto and North of Portugal possesses diverse environments and atmospheres, characterized by a multiproduct offering, targeted at different market segments.

In line with the National Strategic Plan for Tourism (Ministério da Economia e da Inovação 2007) and the Action Plan for Tourism Development in Northern Portugal (Comissão de Coordenação e Desenvolvimento Regional do Norte 2008) as regards the strategic guidelines relating to tourism products and differentiating attributes of the region Porto and Northern Portugal, it was decided to develop the following segments:

1) Primary: urban tourism - city break, business tourism

2) Strategic: cultural tourism, events, scientific tourism, nautical tourism

3) Complementary: Food \& Wine, touring and cultural landscape, health and wellness, nature tourism, religious tourism (profiting from the international status of Porto wine and the Douro Valley).

Urban destinations such as Porto are spaces of concentration of creative, productive and symbolic energy (Florida 2002). The competition that takes place between the cities, which in the current stage of growth and post-industrial era of economic globalization causes them to provide themselves with infrastructure, equipment and strategic services to maintain their hierarchical position, makes them compete not only in terms of the power to attract tourists, but also in relation to the capture of other business and investment opportunities.

Tourists from countries further away are drawn to see the city and experience the activities that happen within it, and are also interested in meeting the people and experience its day-to-day life. For domestic and repeating visitors the attraction of the cities lies in the variety that they offer, encompassing theatres, concerts, music festivals, exhibitions and sport events (Zhang and Marcussen 2007).

Porto must therefore present itself as a multi-sellable destination, with segmentation and suitability of the different tourism products to the different markets. Due to the new tourism demand motivations, seeking ever more to feel experiences, emotions, and events that are special and memorable, and in order to improve the overall quality of these experiences, these products must be integrated and unique, with a clear intention of satisfying, and adding value to the relationship with the territory, from the moment of choosing the destination to the return home (Knudsen and Waade 2010)(Chang and Huang 2007).

It should be noted, however, that planning and management of a destination must be guided by the needs and expectations of the demand side, attracting visitors, tourists, and business to the city and the region (tourism consumption), but also guided by the needs and expectations of those who provide the conditions for meeting this demand, the supply side of the equation (tourism production). This balance between demand, supply and city life is essential for tourism development to take place and must be seen as the foundation for promoting a destination.

Considering that tourism is of strategic importance to the economy of the city and for the regeneration of its historic centre, there is still a great deal of progress to be made 
in this area, in terms of Porto and the Northern region, anchored in the wealth of its material assets, the international recognition of the brands "Porto" and "Douro", and the international visibility of some of its players and infrastructures in the fields of sports, science and culture (Varejão, et al. 2008).

\section{THE TOURISM WEBSITE AS A MARKETPLACE}

The portal is based on the concept of a tourism marketplace (see Figure 1), an integrated tourism information and promotion system that combines a series of tools and technologies for the implementation of an integrated set of solutions.

Figure 1

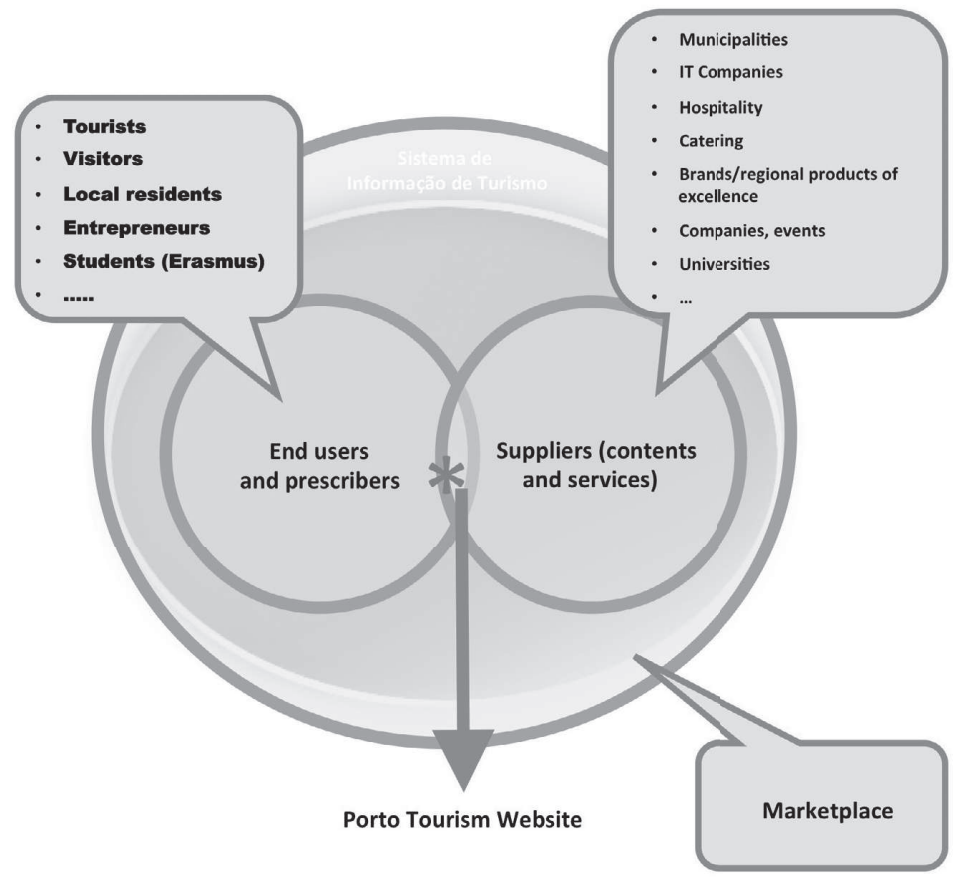

The system supports the monitoring, along the value chain, of the perceived quality, providing and obtaining aggregate data (and individualized data if so consented) of all requests and end user interactions with the suppliers, both while providing information and advice or while purchasing goods and services. Starting from the early stage of trip planning and remote access (e.g. telephone, SMS, email and web), proceeding to the arrival into the city and face to face interactions (e.g. tourist shops, gas stations and tourist information offices), combined possibly with other means of self-information and purchase of goods and services (e.g. reusable Porto Card, interactive kiosks), eventually leaving the 
city to visit other destinations and coming back to Porto for the return journey, allowing a $360^{\circ}$ vision of the interactions between the suppliers and the recipients.

The strategic goal of Porto's Tourism website is contributing to the competitiveness of the city and the region as a whole. The assumption is that Porto has its own values, which should be strengthened, and is the natural starting point for tourists to explore the northern region. Figure 2 shows Porto's main offers.

The website anchor products, at the strategic level, are City-break and Cultural Tourism; and the products being developed: Nature tourism, Business tourism, Health and well-being, Gastronomy and wine (Turismo de Portugal 2011).

The website promotes the coordination and consultation between key tourism stakeholders for the realization of a shared strategy. The Portal is based on the dissemination and promotion of tourism by bringing visibility to regional resources, which are the key elements on which the tourism products are based. The Portal provides broad visibility and enables the partners from the tourism production side to have an active part in managing their space on the Portal. The model developed for the portal covers monitoring information about the dynamics of tourism in Porto, in the framework of regional, national and international tourism.

Figure 2

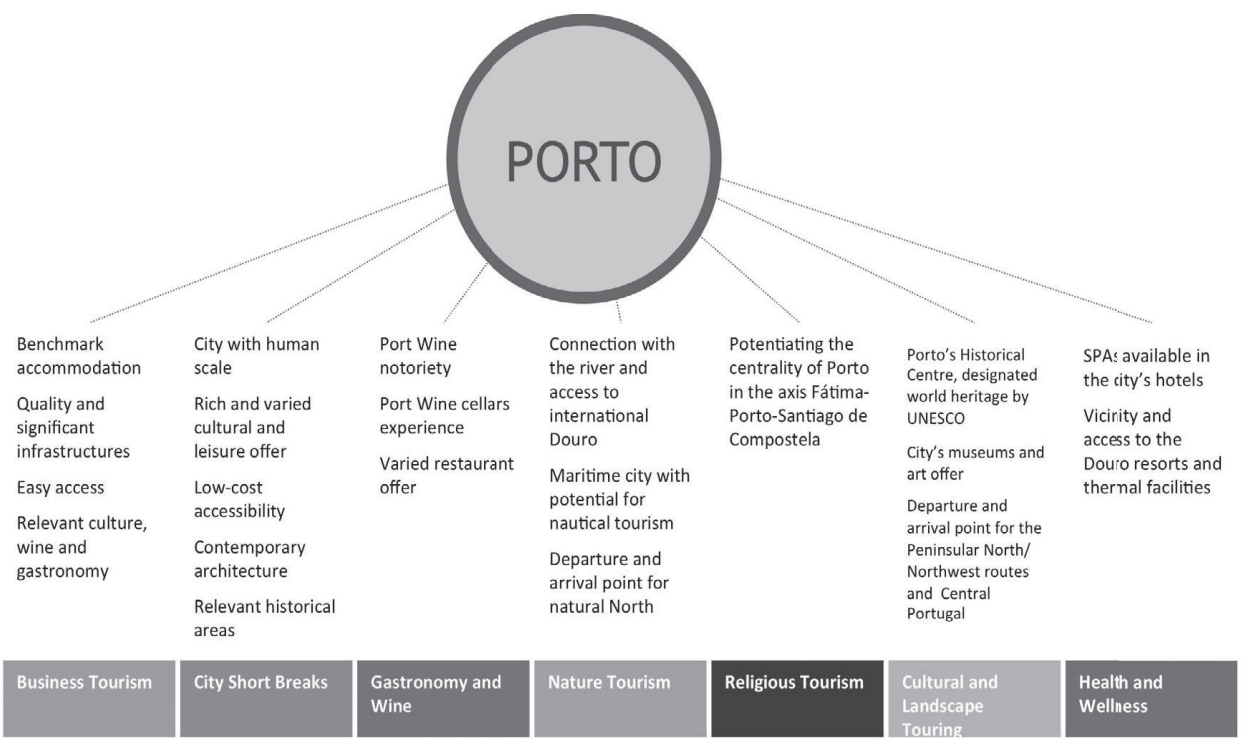


The Website Tourism Portal is an instrument to contribute to strengthening the image of the destinations Porto and Northern Portugal as it offers the potential and real tourist, across the entire value chain of travel (see Figure 3), the discovery of multifaceted and diverse destinations, enhancing the image of the brands and contributing to the development of local and regional economy.

Figure 3
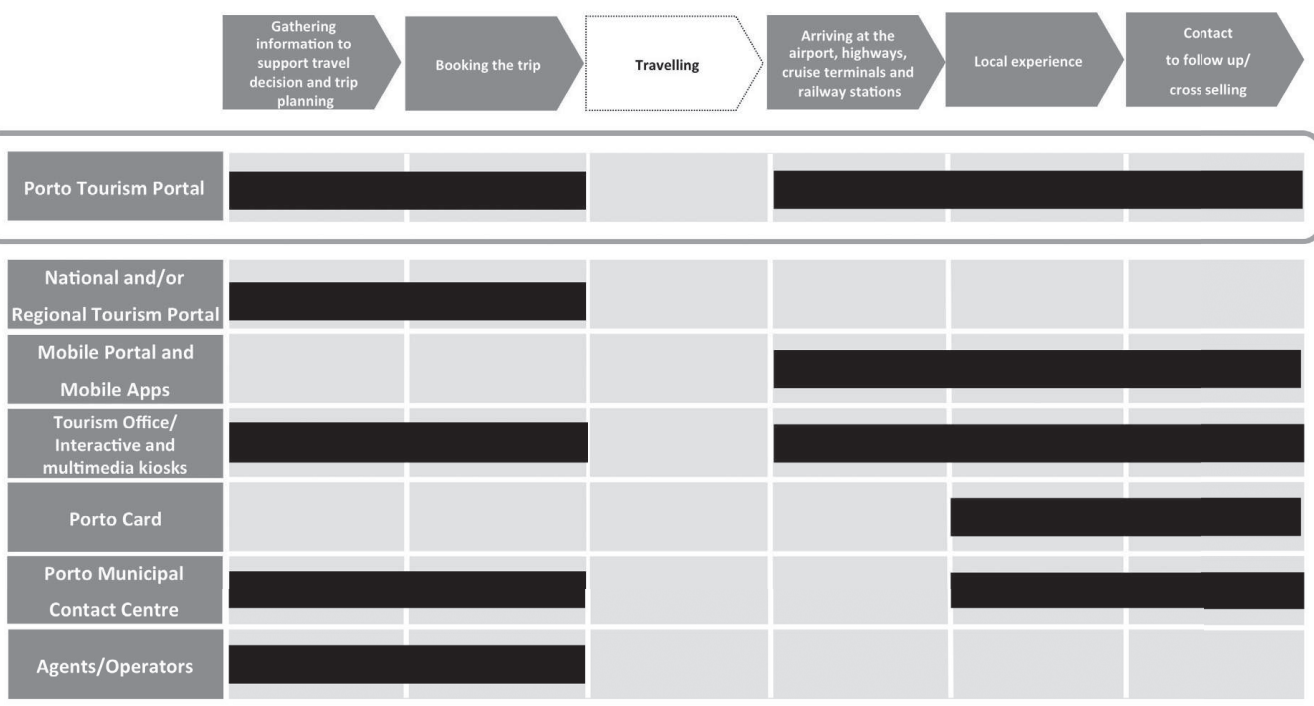

The central objective of the project is to organize, promote and publicize the differentiating aspects of the tourist destination to the national and international market. The goal is to achieve the following specific objectives:

1) Strengthen the trademarks and tourism products in the national and international markets;

2) Create a continuity in terms of image and communication of the different products;

3) Combat seasonality, contributing to the growth in the number of Portuguese and foreign tourists in Porto and Northern Portugal, both in terms of generated revenue and increased length of stay;

The project objectives encompass two main areas: helping to organize the supply oriented to the demand, and to promote the destination. In particular:

- Cataloguing, integrating and systematizing the provision of information, products and services related to the tourism industry of the city and the region in a multichannel communication platform;

- Implementing interactive and transactional services, in a phased manner, with special focus on the GIS component with the integration of multimedia tech- 
nology in intelligent agents for information, communication and fulfilment of services, online reservations and other e-commerce services;

- Leveraging synergies with other partners, initiatives and programs of the municipality and the region, to create business opportunities, particularly for SMEs providing services in the industries of tourism and information technology.

\section{RATIONALE FOR THE DESIGN OF THE WEBSITE}

The challenges: How can the Tourism Portal of the Municipality of Porto become a relevant source of information and promotion of the destination from the customer / traveller point of view? How can the portal become a tool for decision support of all segments that it targets? How can the portal convert potentially interested visitors into consumers? How can the portal become a reference for the various agents involved in the transaction between supply and demand for tourism? How can this online presence help achieve the objective of structuring the promotion of tourism for the destinations Porto and Northern Portugal? What concrete initiatives of the Municipality of Porto are most suitable to achieve these objectives?

Two main vectors were defined: 1) supporting the actions of search and planning;2) structuring the offer. Using these two vectors concrete actions were then defined: the design of measures to facilitate the process of decision making (recommendation) and support for planning (the trip) as a function of pre-defined motivations, identifying and promoting information classified and segmented according to the consumers interests and motivations. From the point of view of structuring the offer the website must be seen as a shop window, showcasing the different products in an orderly fashion.

The guiding principles were: 1) Agents and partners should have an indication of the quality of service provided to other consumers using ratings and comments by consumers, e.g. TripAdvisor (Page 2009); 2) Facilitate comments and recommendations from the Portal and intersect it with social networks (Paris, Lee and Seery 2010); 3) Inform succinctly, offering at a glance all that is essential, avoid using forms too complex and time consuming (e.g. complex travel configurators); 4) Cross product information with the remaining supply and existing infrastructure, present geo-location, access, and complementary equipments; 5) Recommendation engines strengthening the value of the offer depending on the consumer profile (Daramola 2010); 6) Flexibility in structuring the offer in terms of deadlines and budgets using search filters. The tools provided by the website support these guiding principles from the consumer point of view and from the producer point of view.

The development of the website is based on eight assumptions: 1) SEO (search engine optimisation); 2) design, usability and navigation; 3) structuring the offer: information architecture and taxonomy (Morville and Rosenfeld 2006); 4) structuring the offer: segmentation according to the priority targets; 5) transactional services; 6) social referral; 7) promoting the main cultural agents; 8) capture and classification of contacts through user registration; 
Worth highlighting was the effort put in the creation of a database of tourism resources, which is the base for the portal and aims to be the value proposition on promoting the destination in the digital channels and thus contributing to the economic value of the tourism resources.

The concrete actions selected for implementation were:

1) Dossier/Kit "Meet Porto" - Module to promote the city for integration in partner sites. Offering a package of essential city information that can be integrated in the online presence of other agents and partners, it strengths the positioning of the portal as a legitimate source of knowledge about the city and spreads the brand.

2) Cultural Offer-A comprehensive agenda of the city's cultural offerings structured to provide maximum relevance to anyone looking for specific interests.

3) Facilities and Local Services dedicated search engine. Crossing the recommendation of the portal with local facilities and services - Positioning the portal as a provider of quality and relevant information.

4) Pocket guides - essential information about the city. Compilation of essential information of the city tourism supply, in the form of guides, which contain what is necessary for a short visit, allowing the visitor to feel more confident during the stay.

\section{WEBSITE STRUCTURE}

The first phase of the implementation of the website was defining its structure. The three main channels of the Tourism Portal are VISITING, LIVING, and BUSINESS and $\mathrm{R} \& \mathrm{D}$, for which objectives are set in terms of market and segment targets (see Figure 4), the central objective being to support the decision of prescribers and end users in selecting the destination Porto. Highlight for the VISITING channel, which pays particular contribution to the promotion of the Porto brand, the central objective is promoting an extension of the total stay to up to 7 days in Northern Portugal. 
Figure 4

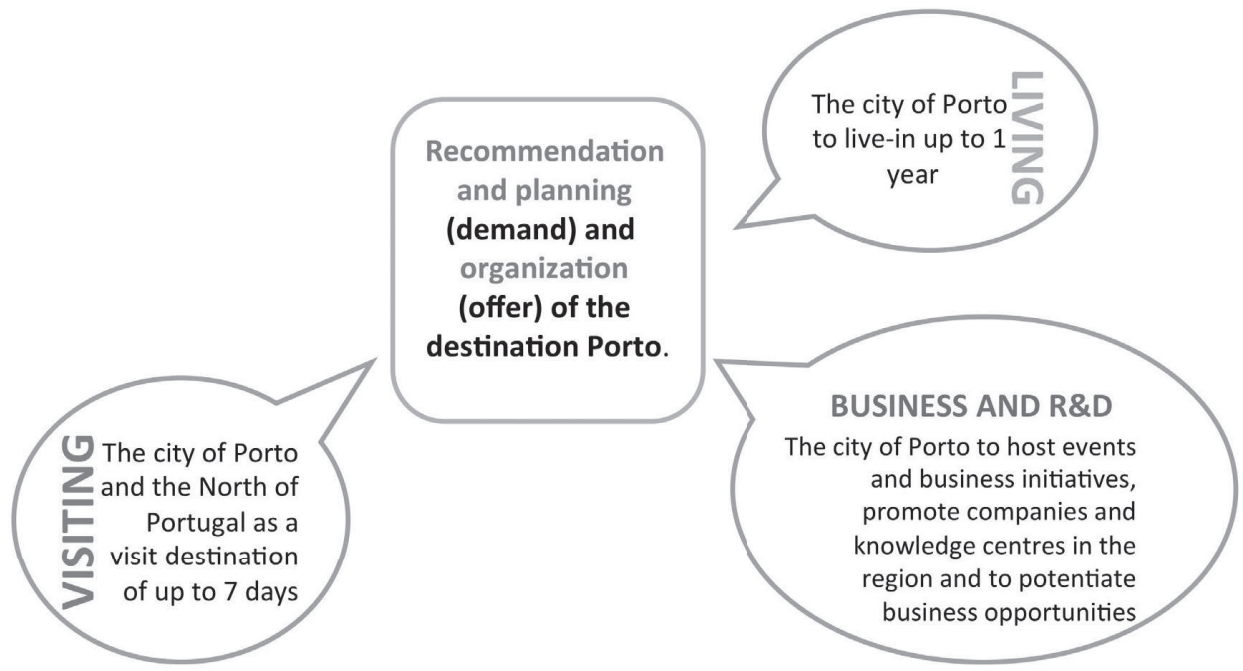

Markets and segments were drawn based on different profiles and analysis of the behaviour of visitors to the destinations Porto and Northern Portugal. We considered in the VISITING channel as priority markets the Portuguese, Spanish, English and German, and as priority segments the interactive travellers, college students and travellers over 55 years. The LIVING channel is essentially aimed at the traditional European market, targeting the sectors medico-pharmaceutical, industry in general, financial services, information technology, and the segments college students, researchers, entrepreneurs and freelancers. Finally, the BUSINESS and R\&D channel includes as well the European market, focusing on the segments of business people, meetings and incentive organizers (event planners), and investors.

These channels are complemented with the transversal channel WHAT'S ON which aims to explore the events of Porto (and surrounding area), linking them to the tourism resources. This strategy is reflected in the cross-presentation of tourism resources and events, enhancing the economic value and promotion of both (e.g. when searching for information about Casa da Música (the House of Music) to be surprised by the presentation and characterization of related tourism resources, as well as its events catalogue).

The segment of cultural tourism that wants a more complete immersion in the destination, both at the time of planning the trip and at the time of stay, has at its disposal the channel CITY OF PORTO which aims at valuing the historical and artistic heritage of Porto. This is an area of more detailed information that will be presented chronologically through a multimedia timeline.

The structure of the Tourism portal presented in Figure 5 sets out the objectives for each thematic channel (Visiting, Living, Business and R\&D, and City of Porto), the large common elements amongst them are the tourism resources database of Porto and Northern Portugal and the events database (nEventos). Each channel promotes specific 
tourism resources trying to enhance the economic value of the tourism resources, organizing them, promoting them and giving them an international scale.

Figure 5

VISITING
. References:
http://mmw.iamsterdam.com
http://mww.yoursingapore.com
http://mmw.visitlondon.com
- The Porto municipality and
Portugal's Northern Region
as visit destination up to 7
clays: routes, tours, geo-
referenced tourism
resources, opportunities,
accommodation, activities,
transports, inclucing the
possibility of planning the
trip combining tourism
resources and events.
- Interactive and transactional
contents and services
- Connection wth the
community, Living@Porto
- Integration with the "Porto and
North of Portugal' Tourism Re-
sources Database, the
"nEventos" everts database
and extemal API's

LIVING
- References:
http://wwwilamsterdam.com and
http://www. vistindondon.com
- The Porto municipality to live in
up to one year: services and
corveniences for those who wish
to be living in Porto up to one
year.
- Interactive and transactional
contents and sevices
- Strong connection with the
community
- Living@Poito
- Integration with the "Porto and
North of Portugal" Tourism
Resources Database.
- Integration with the "hEvertos"
events database

BUSINESS AND RED
- References:
http://frankfuit.de/sixcms/detai.php\%0B?
id=stadtfrankfurt_eval01.c.125162.en
- The Porto municipality to host
events and business initiatives,
promote comparies and
knowiedge centres in the region,
and potentiate business
opportunities.
- Interactive and transactional
contents and services
- Strong connection with the
community
- Living@Porto
- Integration with the "Poito and
North of Poitugal" Tourism
Resources Database
- Integration with the "nEvertos"
events database

\begin{tabular}{|c|}
\hline WHAT'S ON \\
\hline $\begin{array}{l}\text { References: } \\
\text { http://mmw. armsterdam.cm/en' } \\
\text { whats-on }\end{array}$ \\
\hline $\begin{array}{l}\text { http://www.visitondon.com } \\
\text { events/ }\end{array}$ \\
\hline - Events in Porto \\
\hline $\begin{array}{l}\text { - Exploration of contents, ther } \\
\text { richness and impact }\end{array}$ \\
\hline $\begin{array}{l}\text { The importance of usabilly, } \\
\text { use of the search tool and } \\
\text { association with the trip plan }\end{array}$ \\
\hline $\begin{array}{l}\text { - Strong connection with the } \\
\text { communty }\end{array}$ \\
\hline • Living@Porto \\
\hline $\begin{array}{l}\text { - Integration with the "Porto and } \\
\text { North of Portugal" Tourism } \\
\text { Resources Database }\end{array}$ \\
\hline $\begin{array}{l}\text { - Integration with the } \\
\text { "nEventos" } \\
\text { events database }\end{array}$ \\
\hline $\begin{array}{l}\text { - Adoption and integration of } \\
\text { extemal API's, implementing } \\
\text { the Portal's API's }\end{array}$ \\
\hline
\end{tabular}

\begin{tabular}{|c|}
\hline MORE PORTO \\
\hline References: \\
\hline $\begin{array}{l}\text { http://nww.bbc.co._k/history/ } \\
\text { interactive/timelines/british/ } \\
\text { index_embed.shtml (design } \\
\text { interaction and irfographics) }\end{array}$ \\
\hline $\begin{array}{l}\text { - City of Porto, from the tourism } \\
\text { point of view, infographic } \\
\text { information. }\end{array}$ \\
\hline $\begin{array}{l}\text { - Adoption of multimedia } \\
\text { formats to presert the city } \\
\text { (e.g. pictures } 720^{\circ} \text {, video, } \\
\text { testimonials, ...), maps with } \\
\text { georeferenced irformation, } \\
\text { etc. }\end{array}$ \\
\hline $\begin{array}{l}\text { - Strong connection with the } \\
\text { community }\end{array}$ \\
\hline • Living@Porto \\
\hline $\begin{array}{l}\text { - Integration with the "Porto and } \\
\text { Noith of Portugal' Tourism } \\
\text { Resources Database }\end{array}$ \\
\hline $\begin{array}{l}\text { - Integration with the } \\
\text { "nEventos" } \\
\text { events database }\end{array}$ \\
\hline
\end{tabular}

To promote the touristic potential of Porto four more specific areas were developed: LASTMINUTE@PORTO, PLAN YOUR TRIP, SOCIAL NETWORKING, PORTO CARD (see Figure 6). LASTMINUTE@PORTO aims to promote tourism opportunities contributing to the development and promotion of each resource. PLAN YOUR TRIP was designed as a tool for personalized trip planning, i.e., to allow the end user, depending on his/her choices, to automatically create, in a personalized way, a travel roadbook. In order to get feedback on the perceptions of consumers each resource offers links to services for the collection of external suggestions, and interfaces with the social networks Facebook, Foursquare and Tripadvisor. Porto Card is a card that can be purchased and includes discounts and advantages in access to various resources.

Associated with the Tourism Portal and tourism resources database is the implementation of a set of Web APIs (Application Programming Interfaces) - some already existing, whose aim is to be used by external partners in enhancing and creating new products and services (preferably interactive applications or applications for mobile platforms).

After defining the structure of the Tourism Portal and its three main channels, we proceeded to define search criteria and at the same time to organize the information that comprises the tourism resources database. 
Figure 6

OPPORTUNITIES
- Reference:
nttp://mwvilastminute.com
- Special offers based on
Potto's tounism offer.
- Nontransactional, always
redirecting to transactional
site or to the stes of the
respective agents.
- Integration with the
"nEventos"
events database.
- Appication of the Poitals
API's.
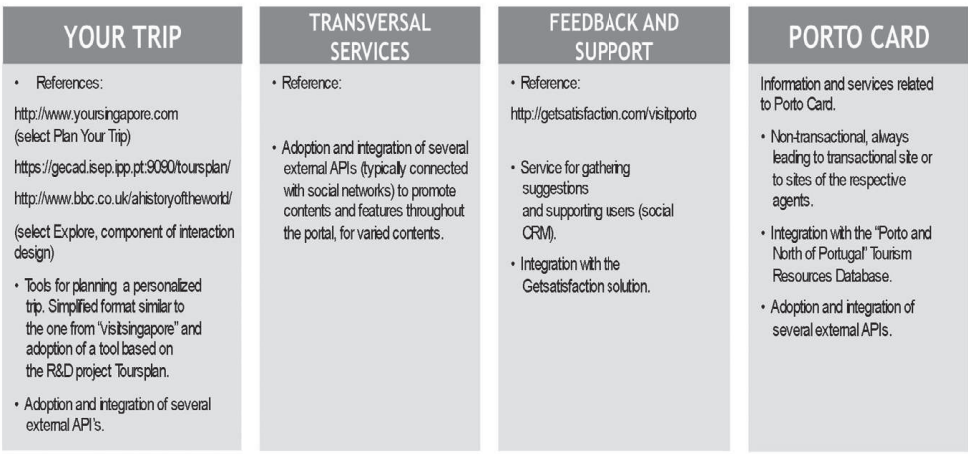

The Tourism Portal is thus based on a set of tools for planning, searching, recommendation and cross-contents fertilization, together they implement a warehouse for the resources to be promoted. Each Channel - Visiting, Living, and Business R\&D - features profiles for searching and organizing the tourism offer, see Figure 7.

Figure 7

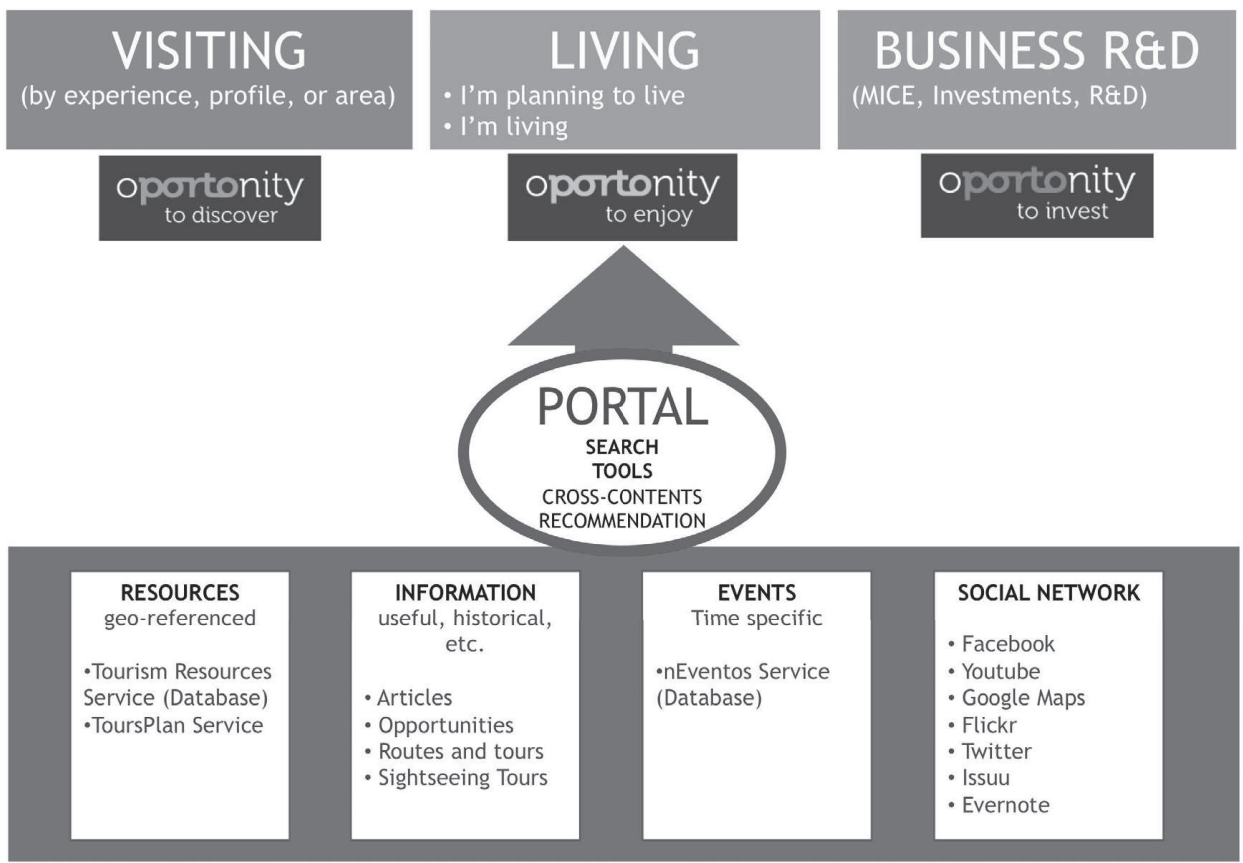

All resources originating from the tourism resources database are geo-referenced to allow the association of all other kinds of references to resources, be they events, planning a specific route, or viewing and commenting resources. The aim is to concentrate 
the diversity of information concerning a particular resource, systematically classifying and segmenting it, thus contributing to enhancing the number of associations that can be automatically made.

\section{INFORMATION ARCHITECTURE}

The second phase of the implementation of the website was creating a development plan for the information architecture of each channel.

The VISITING channel implied the creation of areas of information according to the demand and according to the objectives for the organization and development of the supply and promotion of the destination Porto: Discover, Your Trip, Community, Mobile Apps, Porto Card. Each area of information was organized into sub-themes, and each sub-theme was further divided into areas thus providing a fine-grained classification. This organization allowed the systematization of the provisioning of Points of Interest and information on products and related services. In addition to the main areas of information some complementary transversal areas were implemented, which aim to enhance the portal by linking to other Points of Interest associated with those resources. For example, searching for feature $\mathrm{X}$ in the Tourism Portal might have several other information associated with it, including profiles for whom showed interest into it, shopping opportunities or events associated with the resource, routes into which it is inserted, etc. This complement amplifies the value of the resources (Points of Interest) while promoting the main offer. Figure 8 shows the breakdown of the topics in the areas of information deemed essential for the Visiting channel. 


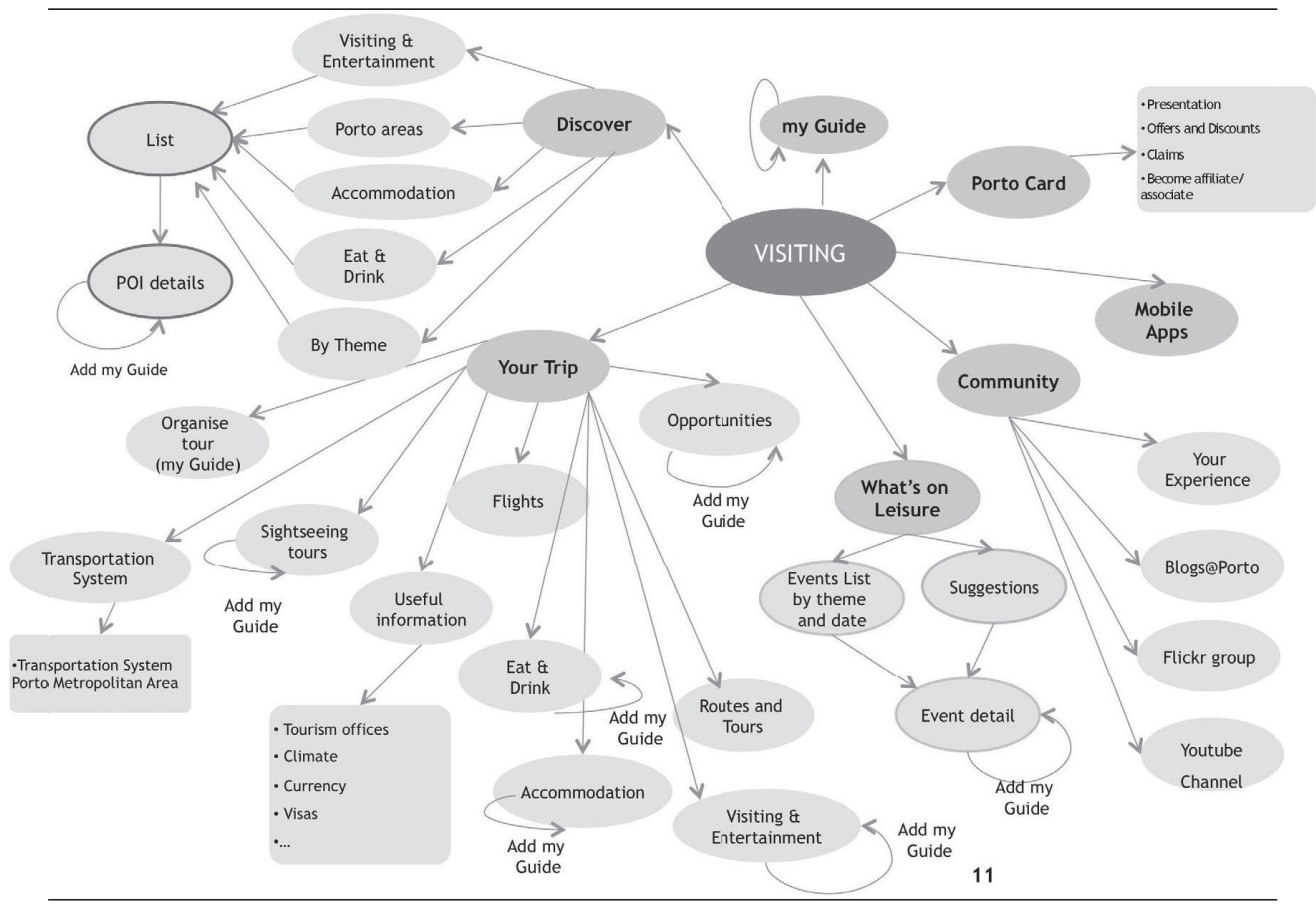

In the Visiting Channel, the area Discover presents a segmentation that aims to facilitate the search for information by the user, that may make his/her choices according to which is more convenient, for instance to filter and search the Porto Zones by topic, Visit \& Entertainment, Accommodation, Eating and Drinking, and other segments (Recommended for ...). Each theme unfolds in information areas that culminate in the detail of the resource. Figure 9 illustrates the information detail designed for the area Discover of the Visiting channel.

The What's On channel allows the user to search for events according to themes, the date of the events, the events information detail or following suggestions made by the Portal. Associated to the What's On channel are other areas of information such as Opportunities and Routes and Tours.

The Living Channel aggregates a series of information and resources for those wishing to live in the city up to one year, whether for work, study or to conduct research (see Figure 10). This channel presents contents common with the Visiting channel such as Eating \& Drinking and Entertainment, and other content, especially in the area of housing, study and research, work, that present useful information content for those planning to live in the city. Notwithstanding the LIVING channel addressing, in a first level, those who come to live in the city, this channel is at the same time, a database of useful information for the region's economic agents. 
Figure 9

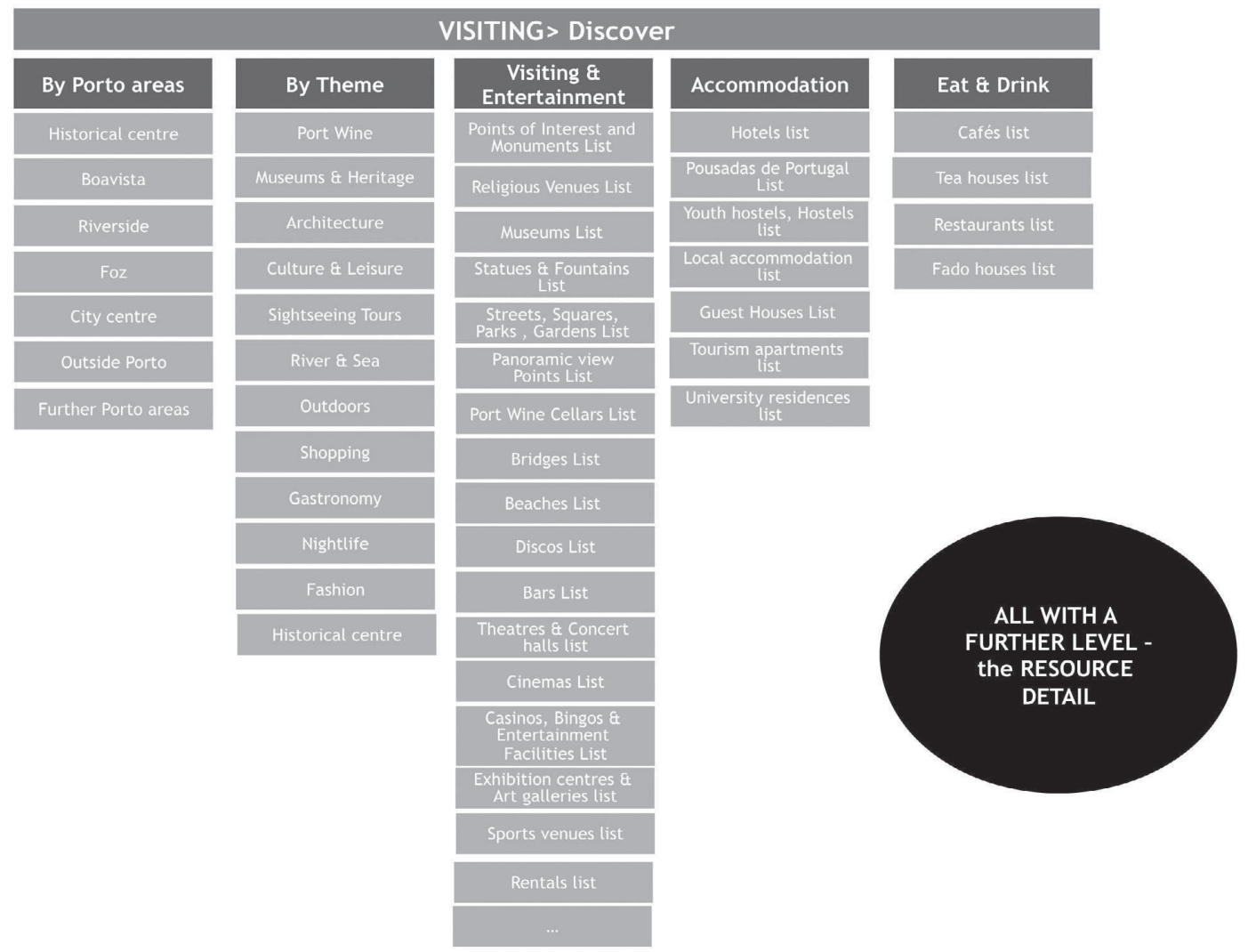

The website tries to make connections between different items of information, thus allowing the user to get the most relevant information according to his/her motivations. In this sense the Living channel is also linked to What's On and Routes and Tours. The Living channel also has an area of Entertainment and Community. The Entertainment area promotes resources associated with the entertainment industry. The Community area is a space dedicated to the exchange of experiences, suggestions and recommendations from those who live(d) and experience(d) the city.

The Business channel is focused in the business community in general. It was designed to be complemented with the leisure segment, thus it has associated to it information on Events and Leisure Tours. Two areas of emphasis to leverage resources and enhance this channel are Investing and Research \& Development. 


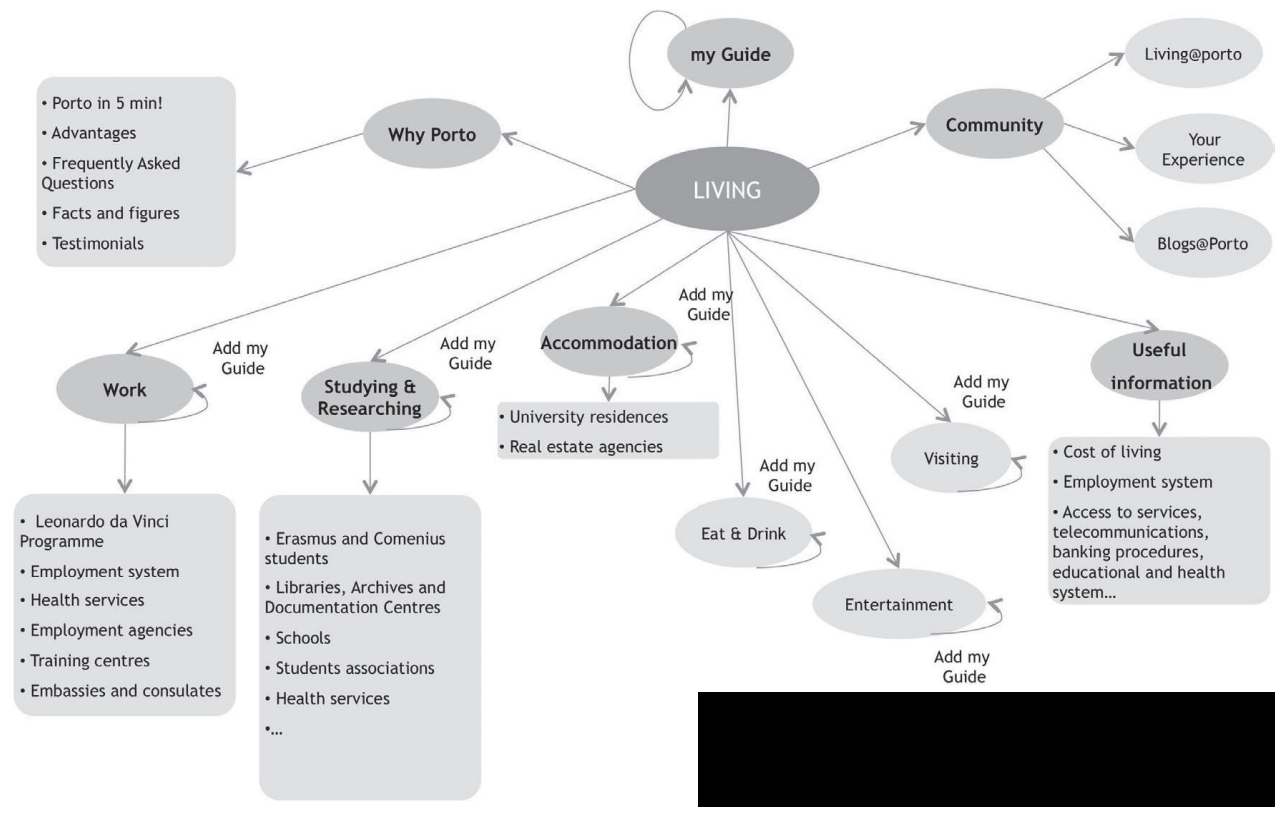

The first consists of an information network that aims to contribute to the uptake of foreign investment in the Metropolitan Area of Porto and in Northern Portugal, the second is intended to map and promote the main centres of R\&D and the Centres for Knowledge and Technology Transfer in Porto and the Northern Region, with emphasis on research centres (see Figure 11). Considering the objectives of promoting tourism, the Business channel includes an area dedicated to the tourism trade, which presents the information most relevant to this area, including the region brochures and a photo gallery, and establishing the link to the business agenda and the personal guide.

The channel More Porto (see Figure 12), brings together information on the history and culture, geography, traditions, heritage and events of Porto and North of Portugal that, due to its importance, help to consolidate the reputation of these destinations and is a factor in attracting a significant number of visitors.

The Personal channel (see Figure 13) allows:

- The user of the Portal to save, manage and share his/her travel to Porto and/or Northern Portugal in order to obtain and provide input, suggestions and recommendations to/from friends;

- The Tourism portal: to collect user data and various information about the use of the website. The collected data (socio-demographic, physical limitations, stereotypes, length of stay, points of interest, and motivations) will be used in aggregate form to serve as the basis for data tools such as Toursplan. 
Figure 11

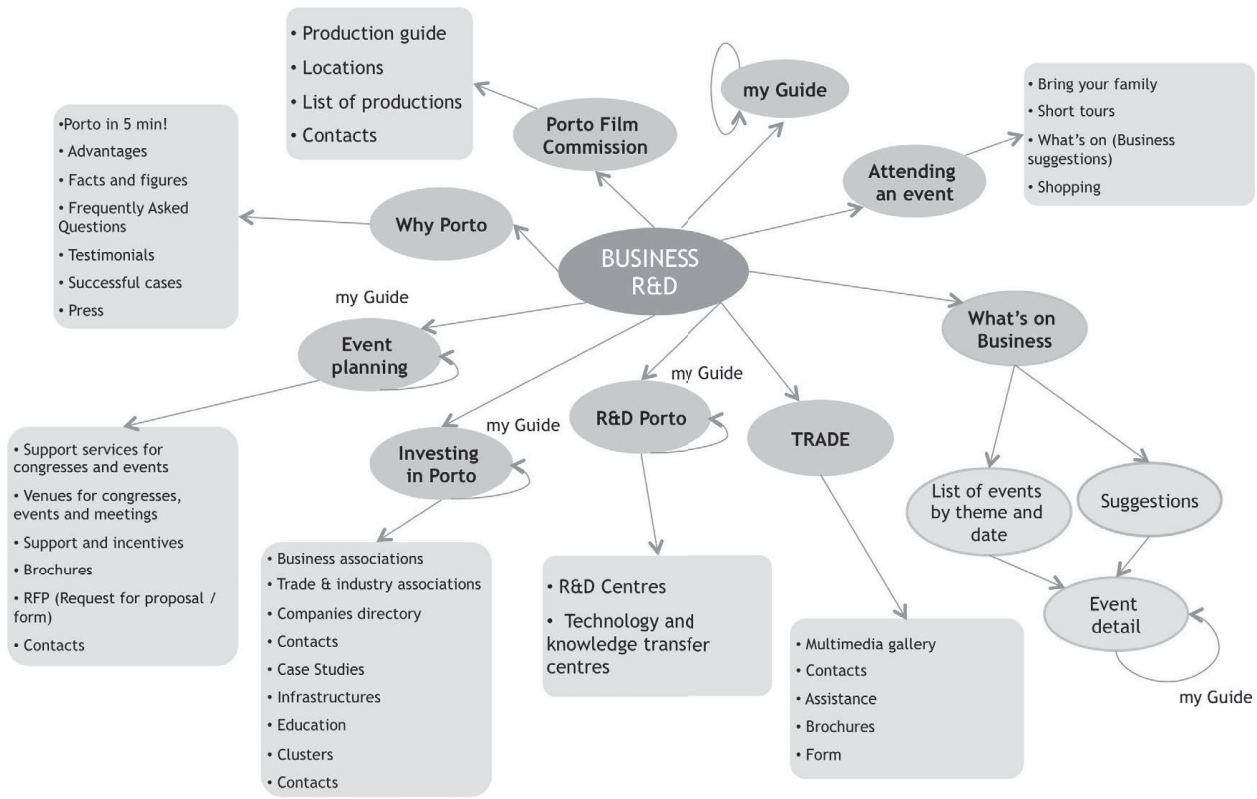

The Toursplan is a Decision Support Service (DSS) which has algorithms and artificial intelligence components developed for the Tourism Portal for personalized recommendations based on user interests and motivations that can be used for route planning taking into account available time, hours, budget and means of travel (Coelho, Almeida and Martins 2009).

Figure 12

\begin{tabular}{|c|c|c|c|c|c|}
\hline \multicolumn{6}{|c|}{ MORE PORTO } \\
\hline $\begin{array}{l}\text { History and } \\
\text { Heritage }\end{array}$ & $\begin{array}{l}\text { Geography and } \\
\text { location }\end{array}$ & Traditions & $\begin{array}{c}\text { Multimedia } \\
\text { gallery }\end{array}$ & Timeline & Events \\
\hline City of Porto & Portugal & Tripeiro / Curiosities & Videos (Youtube) & Happenings & Annual events \\
\hline World Heritage & $\begin{array}{l}\text { The Region and the } \\
\text { Douro Valley }\end{array}$ & $\begin{array}{l}\text { Festivals and } \\
\text { traditions }\end{array}$ & Pictures (Flickr) & Architecture & \\
\hline UNESCO classification & Climate & Gastronomy & & Sports & \\
\hline World heritage site & & Port Wine & & Historical characters & \\
\hline Walking routes & & & & Art & \\
\hline Foreigners in Porto & & & & Literature & \\
\hline The English & & & & Cinema & \\
\hline ... & & & & Music & \\
\hline & & & & Fashion & \\
\hline
\end{tabular}


The TOURSPLAN service has a local database to store the values that associate the user profile to the various elements of the recommendation and planning service. The implementation of this service requires the development of various methods of collection and return of information that are needed to interface service items (e.g. points of interest, events and tours) to obtain the necessary information and synchronize it with the local database. This service will allow providing to registered users of the Tourism Portal recommendations and personalized service and travel planning and resource information. On the other hand the data collected and analysed by the system will provide the basis for recommending future users and contribute to the business intelligence component of the Tourism Information System of the City of Porto.

Figure 13

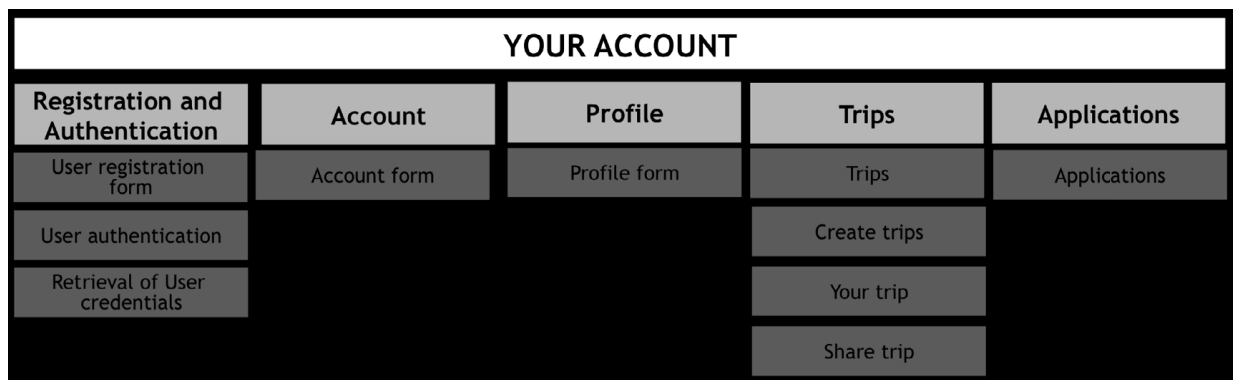

\section{DISCUSSION}

\section{PROJECT MANAGEMENT}

Project management was assigned to a small agile team with a clear mandate that reported to a Steering Committee consisting of the department heads of IT, Marketing, and Tourism of the Municipality of Porto, the head of Porto Digital, and the City Councillor for Tourism (Figure 14). The project leader ensures overall coordination and manages the Permanent Team (PT) consisting of three Team Leaders with functions in the areas of digital contents, interactive and transactional services, marketing and sales, and IT.Each team leader, throughout the project, had various elements temporarily assigned to different activities according to the skills needed in each stage of the implementation of the Portal. With the completion of each phase it started the process of knowledge transfer to the Municipality of Porto, the management of the portal from a product point of view, and integrating the different portal activities in the context of the services of the Municipality of Porto. 
Figure 14

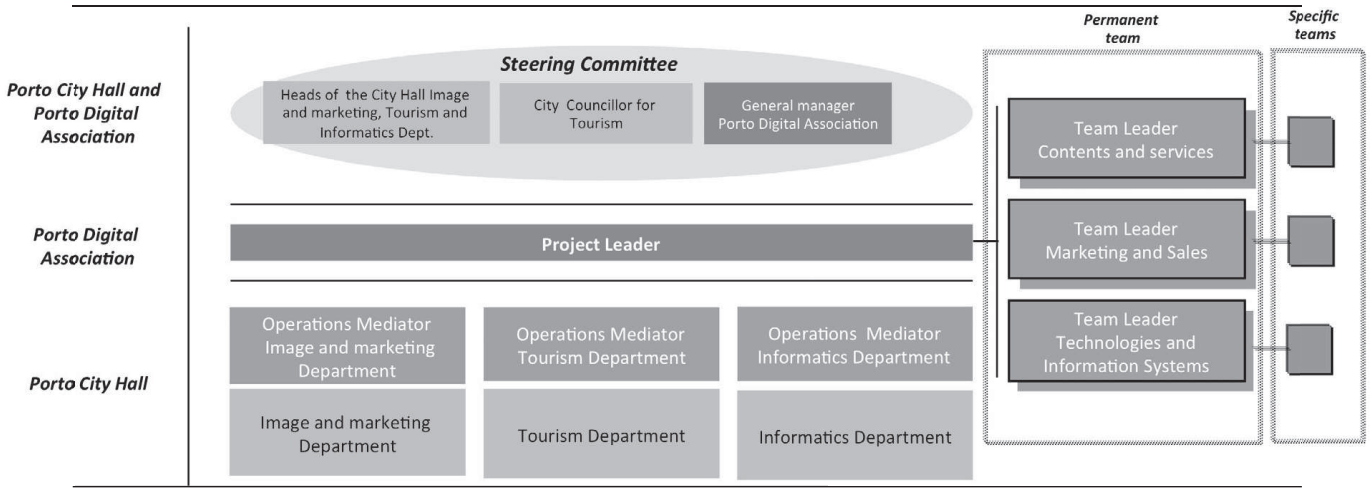

\section{TECHNOLOGY SELECTION AND IMPLEMENTATION TIMELINE}

The project began in February 2010 with the implementation of a strategy document by an internal team; it served as a guideline for the project team. Between April and May 2010 the management team begun the design of the Portal, in line with the general objectives of the mandate and the nature of the Web channel, it identified and defined the main aspects of the organization of the portal: recommendation, planning and structuring the available offer.

In August 2010 the management team and a contractor defined the concept of the Web Portal, followed by the functional design requirements which identified and classified the contents and services (interactive and transactional), main features of the Portal as a function of the main target groups (Yang and Bolchini 2010), the creative concept of the design, prototyping and implementation of the interface, and creation of base templates.

In December 2010 work began on the implementation of the portal. The technology platform selected for content management (CMS) was Microsoft SharePoint Server 2010 Enterprise for Internet Sites (Pattison, et al. 2011) due to the City Hall experience on using that technology on other projects, namely its intranet and extranet, over that platform was implemented a service-oriented architecture (see Figure 15). The framework used for creating the back-office of the tourism resources database (see Figure 16) was GeoDjango (Westra 2010), a Django based framework (Holovaty and Kaplan-Moss 2009) with support for GIS, the data was stored in a Postgresql database (Smith 2010) with the PostGIS extension module, the database schema evolution was handled by the python module South (south.aeracode.org). The work on the first version of the portal was completed by July 2011. With about half of the portal implemented, the portal was inaugurated and entered into production use in May 2011 (see Figure 17); it is expected that the work will be completed by Mars 2013. 
Figure 15
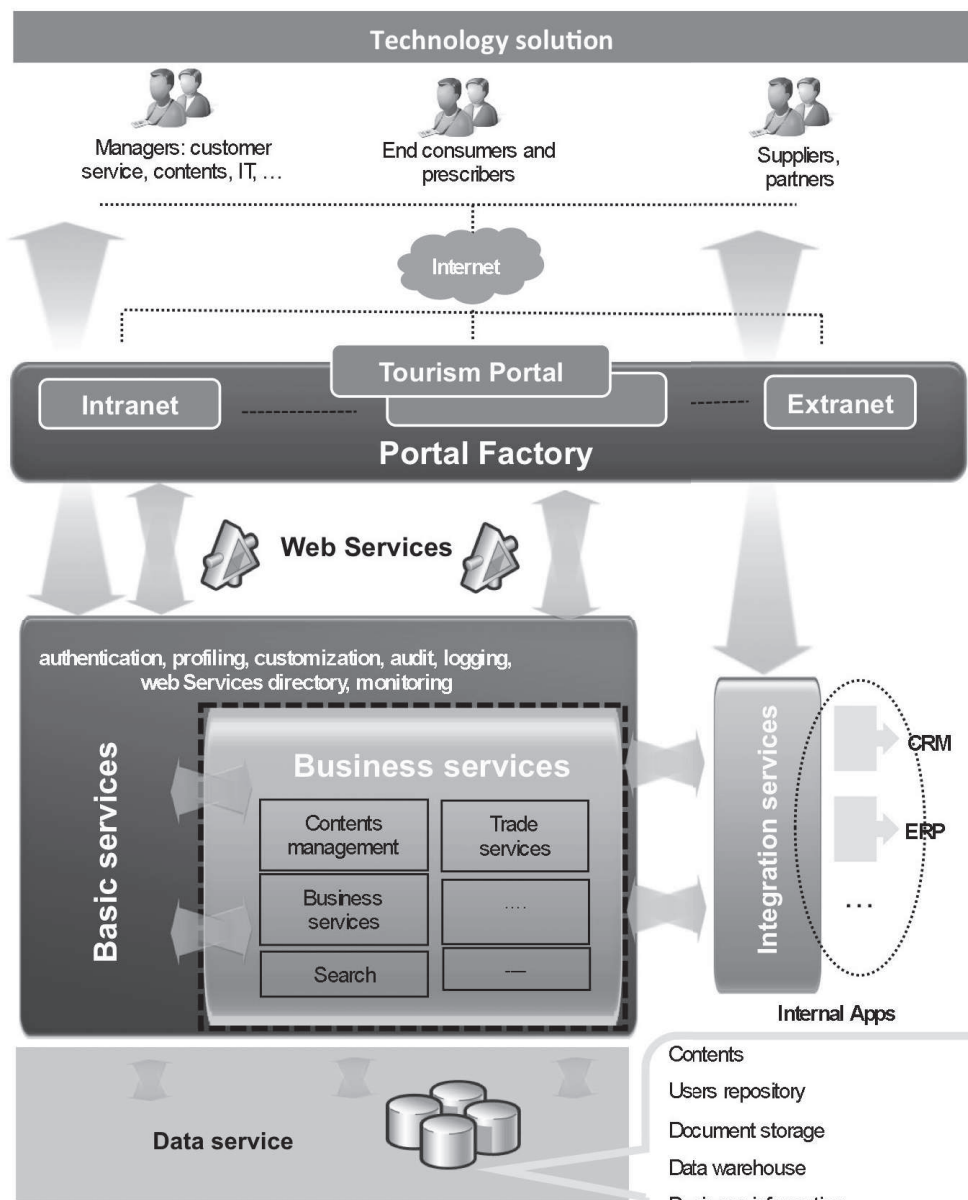

Contents

Users repository

Document storage

Data warehouse

Business information 
Figure 16

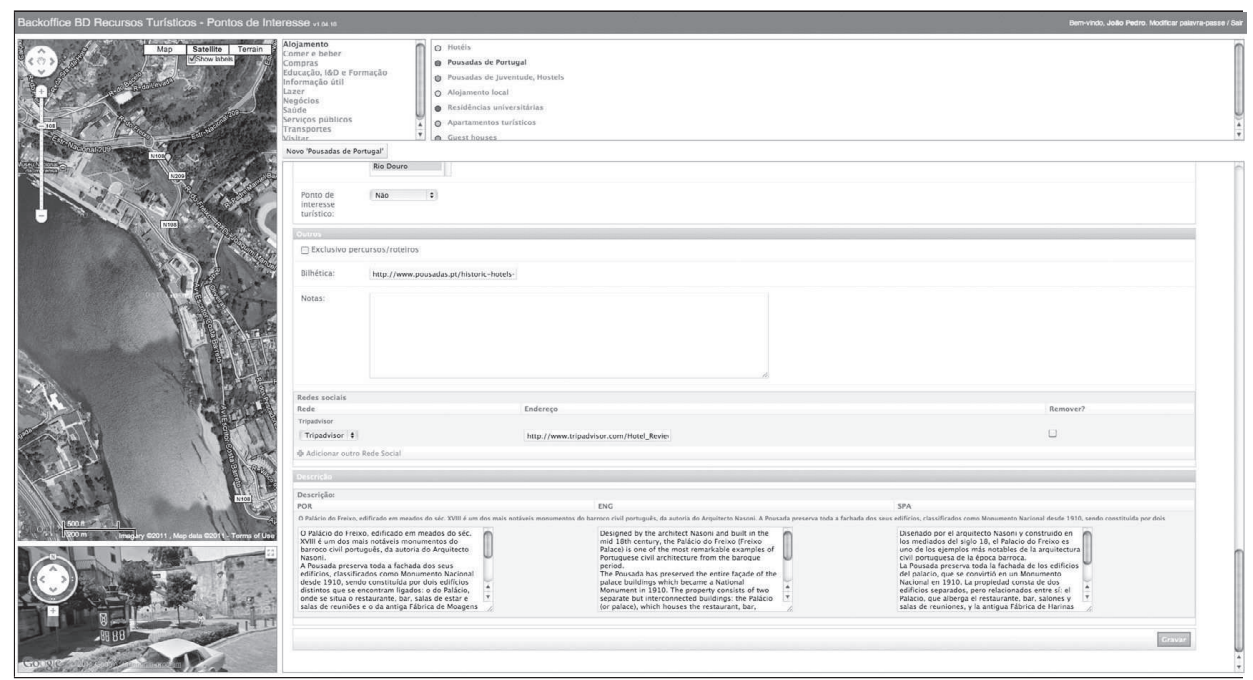

\section{MAIN ISSUES}

The implementation of the Tourism Portal presented some difficult challenges. On the one hand by having a large scope that required working simultaneously on several different fronts, and because, as was to be expected in such a large project, several modifications and changes of scope required making changes to its design and implementation. Also the contractor turned out not to be accustomed to working with this version of Microsoft Sharepoint, therefore the implementation took much longer than expected.On the other hand, because the initially planned allocation of human resources from the different entities involved in creating the portal could not be met and the initially planned budget proved to be scarce, some improvisation had to take place, e.g. the team that created the tourism resources database included exchange students from Spain and the United Kingdom. That manpower was obtained through specific agreements between the Porto Digital Association and their home academic institutions that allowed the exchange students to come to Porto for the duration of a school trimester in order to work on this project.

As it was the first time that this diverse and loosely coupled team tried to create a project of this kind, and as a protection against the large scope and permanent change of requirements, an extensive documentation set was produced to support the design and implementation of the Portal, including concepts, work instructions, definition of taxonomy, document templates, presentations, and many others. This set of documents reached a considerable size and is under permanent revision in order to reflect the existing portal and the still distant goal for the complete product. This documentation set will namely guide the day-to-day work that is being handed over to the internal staff of the Tourism Department of the Municipality of Porto. Here the challenge is whether the maintenance of the tourism portal can be merged into the daily routine of the Tour- 
ism Department, for the time being some progress has been made but it is too early to consider this a success.

Figure 17

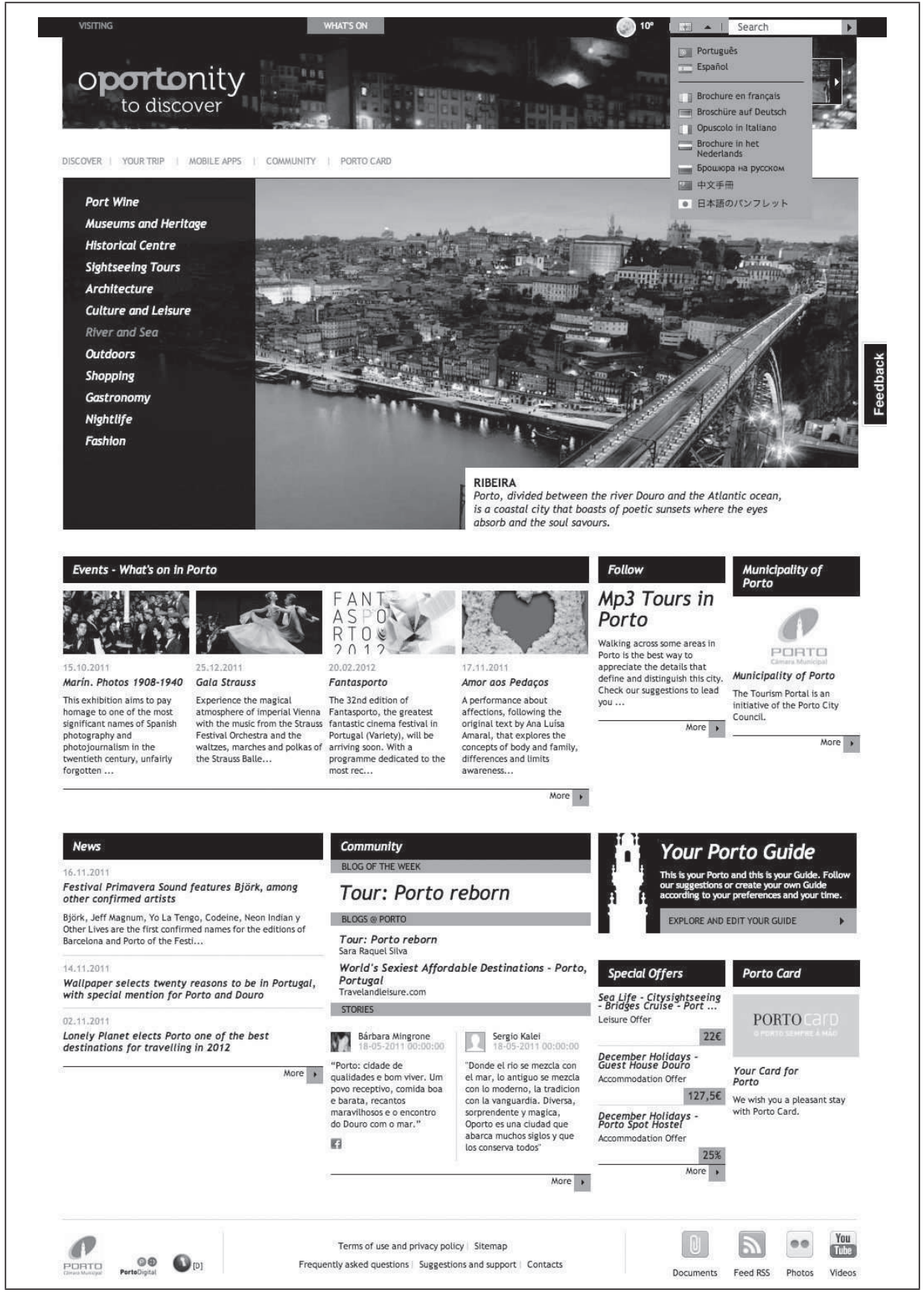


The most important result that this project seems to have achieved is that it managed to catch the interest of the various stakeholders (official bodies, tour operators, IT companies developing products for tourism, tourists, etc.). This is creating an atmosphere of cooperation and exchange of information between entities that although they previously acknowledged the need for cooperation in practice they were working back to back. The project is supplying the contents of the tourism resources database, and of the events database, to the project partners, allowing them to create their own products. One such example is the Farol City Guide of Porto for Android mobile phones (www.farolworld. com), that was developed by the LatitudeN German company using the digital contents created and updated in the context of this project.

\section{RELATED WORK}

In order to find inspiration and define the concept for this web portal a visual and functional benchmarking of several Tourism Portals was made for identification and selection of a set of examples of Portals regarded as good practice. The choice fell on London (visitlondon.com), Madrid (esmadrid.com), New York (nycgo.com) and Singapore (yoursingapoure.com), which were then filtered to the particular circumstances of the Tourism portal of Porto.

After the portal went into full production use, to assess the performance of the Portal within 3 months of the launch (June to August 2011) was carried out a comparative analysis with the tourist portals of London (visitlondon.com), Madrid (esmadrid.com), New York (nycgo.com) and Singapore (yoursingapoure.com), in terms of the number of page views (the more the better), $\%$ of leaving the site after the visualization of a single page (bouncing, the lower the better), and the average time in minutes spent on the site (the more the better). The comparison used the tools provided by the company Alexa (www.alexa.com) and the results were as seen in Figures 18, 19 and 20.

Figure 18

\section{Traffic Rank Reach Pageviews Pagaviewsiluser Bounce \% Time on Site Search \%}

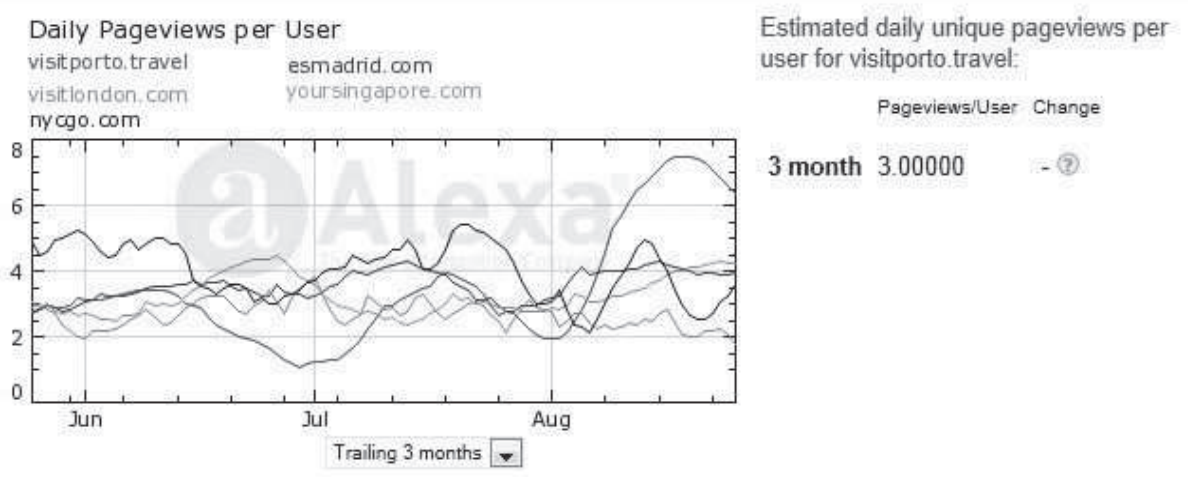


Figure 19

\section{raffic Rank Reach Pageviews Pageviews/User Bounce \% Time on Site Search \%}

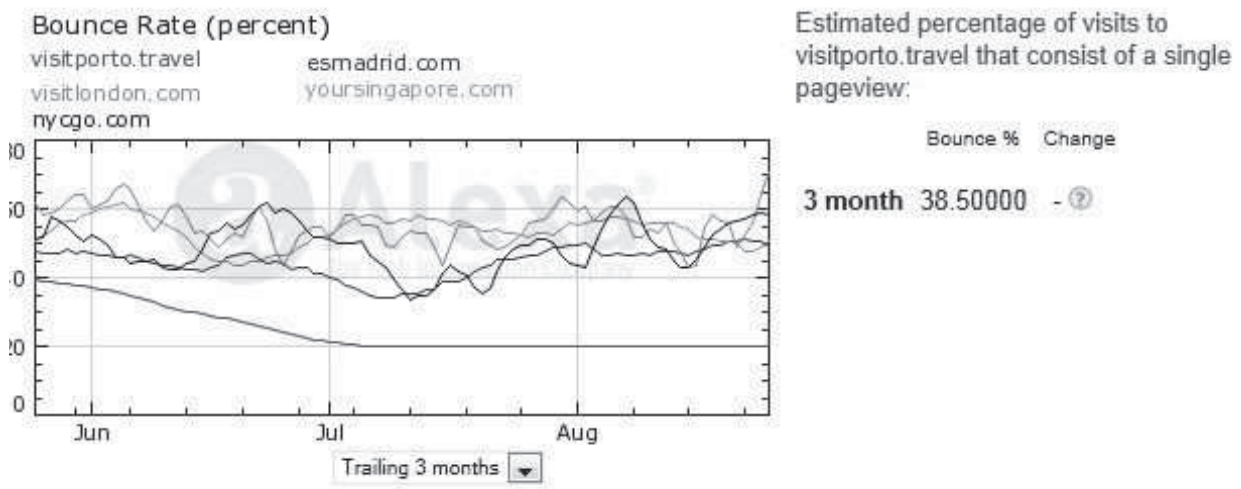

Figure 20

\section{raffic Rank Reach Pageviews Pageviews/User Bounce \% Time on Site Search \%}

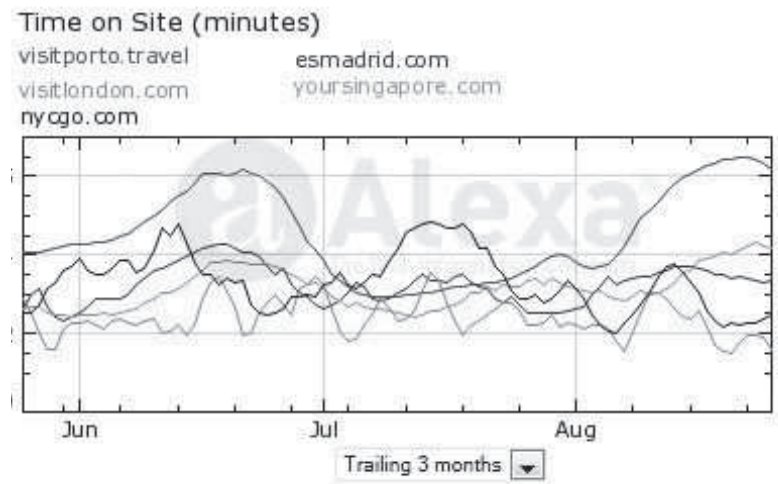

Estimated daily time on site (minutes) for visitporto travel:

$$
\text { Time on Site Change }
$$

3 month $2.64333-$ - ?

From reading the charts it seems that Porto's Tourism Portal had good user adherence when compared with the reference sites in the variables under consideration. Although it even seems to obtain better results than the other sites it is necessary to discount the novelty factor caused by the recent appearance of the portal, only a year from now will it be possible to assess whether this trend continues.

Three other projects are also worth mentioning as they are contributing to this project's goals and there is a flow of information between these projects.

The DouroIntour: Douro Heritage and Cultural Tourismproject (NORTE-02-0169FEDER-000040) aims at creating a tourism website with information on the historic vineyards of the Douro region. This project lead by ISMAI - Instituto Superior da Maia (CEDTUR - Centro de Estudos de DesenvolvimentoTurístico), and that has Porto Digital Association as one of the project partners, is thus collecting geo-referenced information on the wine domains (quintas) together with information on the surrounding heritage, 
nature and tourism interest points. Besides the website proper (dourointour.ismai.pt) a database is also being created with all the information gathered, that database besides powering the website will also be supplied to interested parties so that the information can be integrated into other contexts. One such context is Portal Douro.

The Douro Valleyproject (NORTE-02-0169-FEDER-000005) is lead by the Innovation Centre of Trás-os-Montes and Alto Douro and that has the participation of the Universities of Porto and Trás-os-Montes and Alto Douro and the R\&D Institute INESC Porto. The project goal is to promote the Douro region, a World Heritage site according to UNESCO, in order to attract and retain their "clients" in view of its history, its culture, its landscape admired by foot, boat, train or car, its heritage, its gastronomy and accommodation, their vineyards and wine, and their regional products (www.dourovalley.eu). As such it is a natural complement of the Tourism Portal of Porto.

The iPorto project (Henriques, Rocha e Sousa 2008), that is lead by the Porto Digital Association in cooperation with the Metropolitan Council of Porto, powers the collection of content for the printed cultural events magazine of the Metropolitan Area of Porto, and the corresponding website (iporto.amp.pt). A derived product is the nEvents events database that is used by Porto's Tourism Portal to gather information on cultural and leisure events relevant for tourism.

\section{CONCLUSION}

The development of this project was quite a challenge for the entities involved in its implementation. The bar was placed quite high, the budget and the available time were too small, and it was difficult on a day-to-day basis to allocate the human resources that the project required as most of them were also involved in other tasks outside of the scope of this project. In retrospect the emphasis on creating good and thorough project documentation, in an early phase to seek the involvement of other stakeholders and providing them with incentives to actively participate in the development of the project seems to have been key to the results thus far achieved.

For now, significant progress has been made into the organization of the supply and the involvement of the market, that has seen great potential in this tool to promote their services / businesses and in boosting the global value of the destination. The recent approval by the Committee for the Coordination and Regional Development of the North of Portugal of this project's application to a tourism municipal merit hall was another recognition of the work performed.

\section{REFERENCES}

Buhalis, Dimitrios (2008): “Information Technology in Tourism.” In Tourism Principles and Practice, by Chris Cooper, John Fletcher, Alan Fyall, David Gilbert and Stephen Wanhill, pp. 622-652. Essex: Prentice Hall. 
Chang, T. C., and Shirlena Huang (2007): "Turismo urbano: entre o global e o local." In Compêndio de Turismo, by Alan A. Lew, C. Michael Hall and Allan M. Williams, pp. 255-268. In portuguese. Lisboa: Ciência e Técnica.

Coelho, Bruno, Ana Almeida, and Constantino Martins(2009): "Adaptive Tourism Modeling and Socialization System." The 2009 IEEE International Conference on Social Computing (SocialCom09). Vancouver: IEEE, pp. 645-652.

Comissão de Coordenação e Desenvolvimento Regional do Norte (2008): Plano de Acção para o Desenvolvimento Turístico do Norte de Portugal - Pacto regional para a competitividade da região do norte de Portugal. In portuguese, Porto: Agenda Regional de Turismo.

Comissão de Coordenação e Desenvolvimento Regional do Norte (2011): Programa Regional de Reformas Norte 2020.Public consultation document. In portuguese, Porto: CCDRN.

Daramola, Olawande (2010): Recommendation Services in e-Tourism Systems - A Product line approach. Saarbrucken: VDM.

Florida, Richard (2002): The Rise of the Creative Class. New York: Basic Books.

Henriques, Elena Castro, Marlene Rocha, and Alexandre Valente Sousa (2008): "iPorto 2.0, a collaborative software platform for low-cost dissemination of cultural and tourist information." Edited by A. Barros Cardoso, Claudine Durbiano and Eduardo Cordeiro Gonçalves. Enoturismo e Turismo em Espaço Rural.Porto: Edições ISMAI, pp. 331-341 (http://portodigital.pt/avs/iPortoPaperNov2008/).

Holovaty, Adrian, and Jacob Kaplan-Moss (2009): The Definitive Guide to Django. 2nd Edition. Berkeley: Apress.

Knudsen, Britta Timm, and Anne Marit Waade (2010): "Performative Authenticity in Tourism and Spatial Experience: Rethinking the Relations Between Travel, Place and Emotion." In Re-Investing Authenticity - Tourism, Place and Emotions, edited by Britta Timm Knudsen and Anne Marit Waade, 1-19. Bristol: Channel View Publication.

Ministério da Economia e da Inovação (2007): Plano Estratégico Nacional do Turismo - Para o desenvolvimento do turismo em Portugal. In portuguese, Lisboa: Turismo de Portugal, IP.

Morville, Peter, and Louis Rosenfeld (2006): Information Architecture for the World Wide Web - Designing large scale web sites. 3rd Edition. Sebastopol: O'Reilly.

Page, Stephen J. (2009): "Social Networking and Tourism." In Tourism Management: Managing for change, by Stephen J. Page, pp. 332-334. Oxford: Butterworth-Heinemann.

Paris, Cody Morris, Woojin Lee, and Paul Seery (2010): “The Role of Social Media in Promoting Special Events: Acceptance of Facebook 'Events'." Edited by Ulrike Gretzel, Rob Law and Matthias Fuchs. Information and Communication Technologies in Tourism. New York: Springer, pp. 531-541.

Pattison, Ted, Andrew Connell, Scot Hillier, and David Mann (2011): Inside Microsoft SharePoint 2010. Sebastopol: O’Reilly Media. 
Shaw, Gareth, and Allan M. Williams (2002): Critical Issues in Tourism - A Geographical Perspective. 2nd Edition. Oxford: Blackwell Publishing.

Smith, Gregory (2010): PostgreSQL 9.0 High Performance.Birmingham: Packt Publishing.

Turismo de Portugal (2011): Plano Estratégico Nacional do Turismo - Propostas para revisão no horizonte 2015, versão 2.0. Ministério da Economia, da Inovação e do Desenvolvimento, In portuguese, Lisboa: Turismo de Portugal, IP.

Varejão, José, Anabela Martins, Luís Delfim Santos, and González Pilar (2008): A Base Económica do Porto e o Emprego. Gabinete de Estudos e Planeamento, Porto: Câmara Municipal do Porto.

Westra, Erik (2010): Python Geospatial Development. Birmingham: Packt Publishing.

Yang, Tao, and David Bolchini (2010): "Quantifying Brand Values Perception in Destination Websites: a Design Requirements Perspective.” Edited by Ulrike Gretzel, Rob Law and Matthias Fuchs. Information and Communication Technologies in Tourism 2010. New York: Springer, pp. 309-320.

Zhang, Jie, and Carl Marcussen (2007): "Tourist motivation, market segmentation and marketing strategies." 5th Bi-Annual Symposium of the International Society of Culture, Tourism, and Hospitality Research. South Caroline. 